\title{
Jum 2rubau der fithte.
}

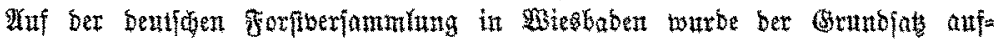

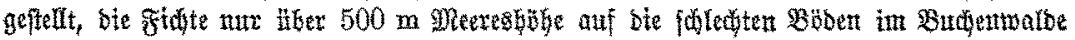
eimzubaten.

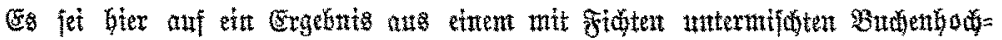

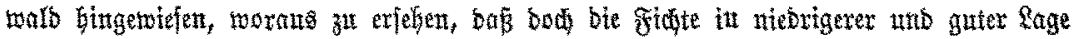

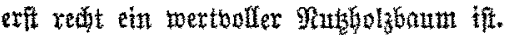

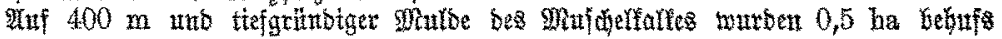

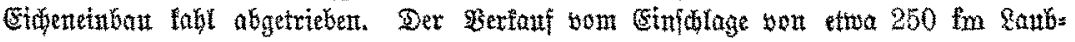

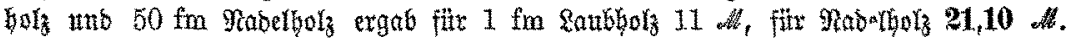

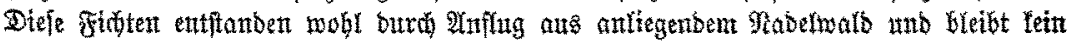

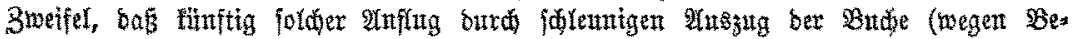

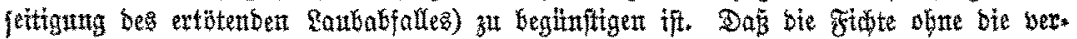

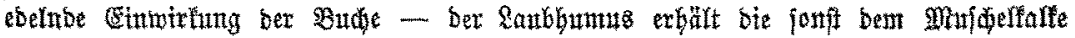

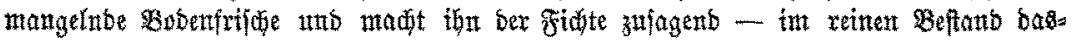

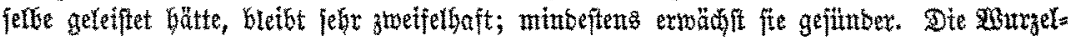

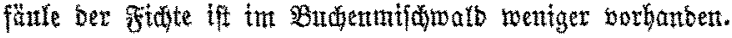

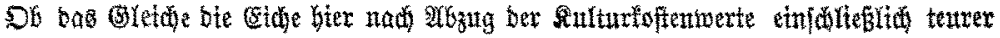

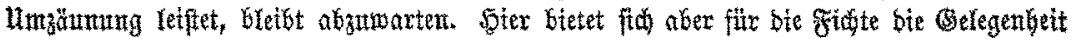

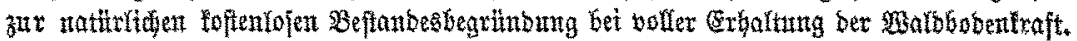

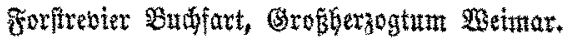

\section{J̄ur Waldbran $\delta$-Statiftit.}

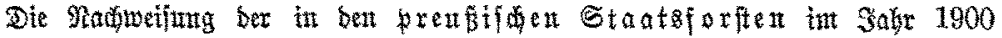

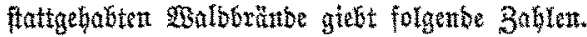

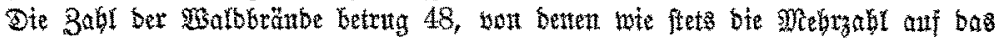

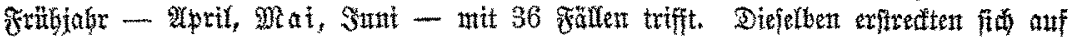

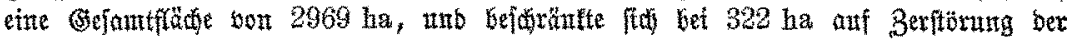

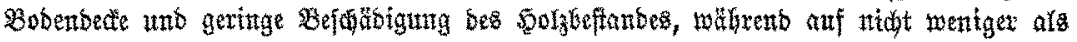

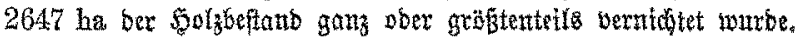

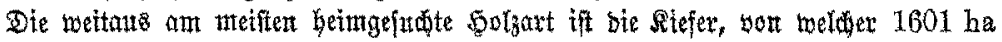

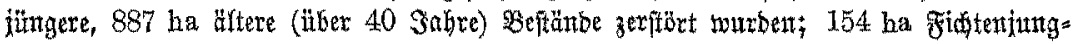

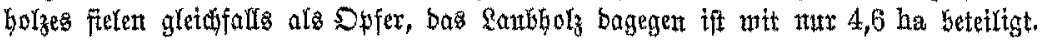

Bas entblito bie Entfthungsurjacten anbelangt, fo benennt jente Statifif als

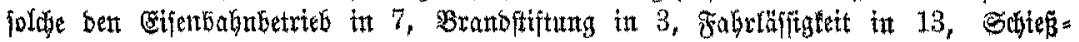

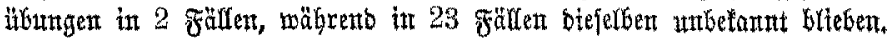

\section{hochiłhul =2Tađtriditen.}

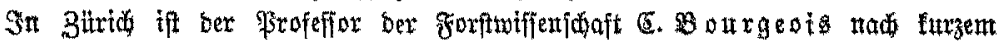
Sramtentlager int Wrter bon nur 46 Safien berftorben. Derfelbe war als Radfolger

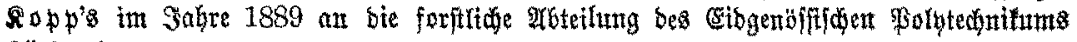
Bürid) bertufen worbent.

Im 9. Sttober sexfarb raft thb utserwartet Whofeffor Dr. Robert Saxtig it

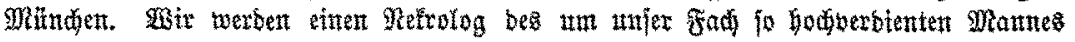
in einen bex nädiften 5elte britgen. 